Volume 2 Nomor 2, Juli-Desember 2018: hlm. 75-84. Magister Ilmu Hukum, Fakultas Hukum, Universitas Lampung, Bandar Lampung, Lampung, Indonesia. E-ISSN: 2598-3105 P-ISSN: 2723-2581 http://jurnal.fh.unila.ac.id/index.php/cepalo

\title{
BEGAL ANAK; PEMENUHAN HAK DAN LEMBAGA PEMBINAAN KHUSUS ANAK KELAS II A BANDAR LAMPUNG
}

\section{FULFILLMENT OF THE RIGHTS OF THE CHILD IN THE CLASS II SPECIAL CHILD COACHING INSTITUTION IN BANDAR LAMPUNG}

\author{
Eka Intan Putri \\ Lembaga Konsultan Bantuan Hukum Intan \\ Intanputri2011@gmail.com
}

\begin{abstract}
Abstrak
Perlindungan anak adalah segala kegiatan untuk memastikan pelaksanaan terjaminnya hak anak-anak, tak terkecuali juga hak anak-anak sebagai seorang anak pidana begal. Pembegalan merupakan kejahatan dan penyimpangan dalam masyarakat yang juga melanggar norma sosial, dimanapun serta dilakukan oleh siapapun. Seringkali terdengar bahwa masih adanya keluhan dari keluarga dan narapidana anak terhadap dugaan pelanggaran pelaksanaan hak hak anak pidana begal di "Lembaga Pembinaan Khusus Anak (LPKA)", bahkan anak pidana juga rentan mengalami kekerasan dari temannya sesama anak pidana. Dalam penelitian ini, penulis akan menggunakan metode pendekatan yuridis empiris serta yuridis normatif. Penelitian ini akan menggunakan data sekunder dan primer, data sekunder terdiri dari bahan hukum primer, sekunder serta tersier. Penelitian ini akan menggunakan analisis data kualitatif. Dari hasil penelitian diperoleh kesimpulan bahwa pelaksanaan hak-hak anak sebagai anak pidana begal di LPKA Klas II Bandar Lampung, mengacu pada Undang-Undang Nomor 11 Tahun 2012 tentang Sistem Peradilan Pidana Anak, serta berpedoman pada Undang Undang Nomor 12 Tahun 1995 tentang Pemasyarakatan. Dari 13 (tiga belas) hak-hak anak sebagai anak pidana begal, ada 11 (sebelas) hak anak pidana begal yang sudah terlaksana meskipun belum sempurna. Akan tetapi masih ada kendala yaitu faktor penghambat dari masyarakat dan aparat penegak hukum, yakni tidak ada kepedulian keluarga terhadap anak pidana begal, dalam hal kesehatan, pendidikan, serta pembinaannya, adapun pembinaan anak pidana begal dipasrahkan sepenuhnya kepada petugas di LPKA, serta kurangnya koordinasi antara Instansi terkait yaitu Kejaksaan Negeri dan Pengadilan Negeri dengan Lembaga Pembinaan Khusus Anak (LPKA).
\end{abstract}

Kata Kunci: Pelaksanaan, Hak-hak anak, anak pidana begal, Lembaga Pembinaan Khusus Anak (LPKA)

\section{Abstract}

Child protection is all activities to ensure the implementation of the guaranteed rights of children, including the rights of children as criminals. Legalization is a crime and deviation in society that also violates social norms, wherever and done by anyone. It is often heard that there are still complaints from families and convicted children regarding alleged violations of the implementation of the rights of criminal child rights in the "Special Child Development Institution (LPKA)", even criminal children are also vulnerable to violence from fellow criminals.

In this research, the writer will use empirical and normative juridical approaches. This study will use secondary and primary data, secondary data consisting of primary, secondary and tertiary legal materials. This research will use qualitative data analysis. From the results of the study it was concluded that the implementation of children's rights as criminal offenses in LPKA Class II Bandar Lampung, referring to Law Number 11 of 2012 concerning the Criminal Justice System for Children, and guided by Law Number 12 of 1995 concerning Correctional 
Facilities. Of the 13 (thirteen) children's rights as criminal offenders begal, there are 11 (eleven) rights of criminal offenders that have been implemented even though it is not yet perfect. However, there are still obstacles, namely inhibiting factors from the community and law enforcement officers, namely there is no family concern for criminal children, in terms of health, education, and guidance, while fostering criminal children is completely surrendered to officers in LPKA, and the lack of coordination between Related agencies are the District Attorney and the District Court with the Special Child Development Institute (LPKA).

Keywords: Implementation, Children's Rights, Criminal Offenses, Begins Special Development for Children (LPKA)

Cara Mengutip (How to Cite): Eka Intan Putri, "Begal Anak; Pemenuhan Hak dan Lembaga Pembinaan Khusus Anak Kelas II A Bandar Lampung”, Jurnal Cepalo, 2 (2), (2018): 75-84.

DOI: https://doi.org/10.25041/cepalo.v2no2.1764

\section{A. Pendahuluan}

Pada dasarnya hukum adalah pencerminan dari HAM, sehingga hukum itu mengandung keadilan atau tidak akan ditentukan oleh Hak Asasi Manusia yang terkandung dan juga diatur atau dijamin dalam hukum tersebut. Hukum tidak akan lagi dilihat sebagai cerminan dari kekuasaan semata-mata, namun juga harus mencerminkan perlindungan terhadap hak-hak para warga negara. ${ }^{1}$ Pendapat Marthen Kriale dalam buku Nurul Qamar, menyatakan bahwa Hak Asasi Manusia adalah hak yang berasal dari Tuhan, sedangkan Jack Donnaly, mengartikan Hak Asasi Manusia sebagai hak yang berasal dari hukum alam, tetapi sumber utamanya adalah Tuhan. ${ }^{2}$ Dalam Undang-Undang Nomor 4 Tahun 1979 tentang Kesejahteraan Anak mengatakan bahwa "Dalam membangun serta mengurus rumah tangga, suatu bangsa wajib membina penghidupan dan membentuk kepribadian. Usaha tersebut adalah usaha yang berkelanjutan dari generasi ke generasi. Guna menjamin usaha tersebut, dibutuhkan seorang pendamping dari generasi terdahulu untuk mendampingi generasi baru dalam menjalankan tugas tersebut. Tugas ini akan dapat terlaksana apabila generasi baru tersebut mampu memiliki tingkah laku yang sesuai dengan norma-norma sosial dalam masyarakat. ${ }^{3}$

Menurut A.Syamsudin Meliala dan E.Sumaryono dalam buku Maidin Gultom, terdapat faktor penyebab yang dapat mempengaruhi timbulnya kejahatan anak, faktor tersebut adalah faktor lingkungan, ekonomi/sosial, serta psikologis. Menurut Kartini Kartono kriminalitas adalah dampak dari ketidakmampuan seseorang dalam mengendalikan emosi-emosi primitif. Menurut Bismar Siregar dalam buku yang sama, belum siapnya masyarakat dalam menerima modernisasi akan berdampak pada kenakalan anak, damapak dari modernisasi tersebut dapat berupa rumah tangga yang terbengkalai dikarenakan ke2 orang tua yang mencari nafkah sehingga anak akan kekurangan kasih sayang dan perhatian dari orang tua. ${ }^{4}$ Kejahatan telah menjadi permasalahan seluruh negara. Pada dasarnya kejahatan banyak yang disebabkan oleh faktor kemiskinan, dalam suatu masyarakat yang memiliki sumberdaya alam yang minim, kejahatan akan banyak terjadi dalam masyarakat tersebut, dengan berjalannya waktu kini kejahatan dapat muncul dari faktor kemakmuran. ${ }^{5}$

Perlindungan anak secara garis besar memiliki 2 perbedaan pengertian:

1. Perlindungan anak yang bersifat yuridis: bidang hukum publik dan hukum keperdataan.

2. Perlindungan anak yang bersifat non yuridis: bidang sosial, bidang kesehatan dan bidang

\footnotetext{
${ }^{1}$ Maidin Gultom, Perlindungan Hukum Terhadap Anak Dalam Sistem Peradilan Pidana Anak di Indonesia, Bandung: Refika Aditama, (2013), hlm 7.

${ }^{2}$ Nurul Qamar. Hak Asasi Manusia dalam Negara Hukum Demokrasi (Human rights in Democratiche Rechtsstaat), Jakarta: Sinar Grafika, (2016), hlm 16.

3 Mohammad Taufik Makarao, Letkol Sus, Weny Bukamo, Syaiful Azri. Hukum Perlindungan Anak Dan Penghapusan Kekerasan Dalam Rumah Tangga, Jakarta: Rineka Cipta, (2013), hlm. 11-12.

${ }^{4}$ Maidin Gultom, Op.Cit., hlm. 58.

${ }^{5}$ M. Ali Zaidan, Kebijakan Kriminal, Jakarta: Sinar Grafika, (2016), hlm. 1.
} 


\section{pendidikan. ${ }^{6}$}

Bidang yuridis berkaitan dengan semua aturan hukum yang memiliki dampak langsung bagi kehidupan anak dalam segala aturan hukum yang mengatur tentang kehidupan seorang anak. ${ }^{7}$ Perlindungan terhadap hak-hak anak dalam suatu sitem peradilan pidana anak menurut Arief Gosita dalam buku Nikmah Rosidah, adalah merupakan suatu kegiatan yang memiliki tujuan untuk menjamin kesejahteraan rohani dan jasmani anak berdasarkan kepentingan dan hak asasi yang dimilikinya. ${ }^{8}$ Seperti halnya yang telah tercantum dalam Pasal 20 Undang- Undang Nomor 23 Tahun 2002 menentukan: "Negara, pemerintah, masyarakat, keluarga, dan orang tua berkewajiban dan bertanggungjawab terhadap penyelenggaraan perlindungan anak"9

Konvensi Hak Anak (KHA) yang sudah diratifikasi melalui Keputusan Presiden Nomor 36 Tahun 1990, menginstruksikan kaidah tersebut ke dalam hukum nasional, maksudnya pemerintah memiliki sebagai negara peserta (state party) mengikatkan diri dan sekaligus menggunakan konvensi tersebut sebagai sumber hukum nasional yang berkaitan dengan implementasi konvensi hak anak, mempunyai 2 konsekwensi hukum, yaitu mengakui hak-hak anak ( legislation of children right), kewajiban negara untuk melaksanakan dan menjamin terlaksananya hak-hak anak (enforcement of children rights) $;^{10}$

Asas yang digunakan dalam sistem peradilan anak adalah: asas pelindungan, keadilan, proporsional, non diskriminasi, penghargaan terhadap pendapat anak, pembinaan dan pembimbingan anak, kelangsungan hidup dan tumbuh kembang anak, kepentingan terbaik bagi anak, perampasan kemerdekaan dan pemidanaansebagai upaya terakhir, dan penghindaran pembalasan. ${ }^{11}$ Menurut Sudarto dalam buku Eddy O.S. Hiariej, fungsi hukum pidana terbagi menjadi dua bagian yaitu fungsi umum dan fungsi khusus. Fungsi umum dalam hukum pidana mirip seperti fungsi hukum pada umumnya ialah menciptakan masyarakat yang teratur, sedangkan fungsi khususnya yaitu memberikan perlindungan terhadap kepentingan hukum dengan sebuah sanksi. ${ }^{12}$

Data di Lembaga Pembinaan Khusus Anak (LPKA) sepanjang tahun 2016 terdapat sebanyak 198 orang anak yang menjadi anak pidana. ${ }^{13}$ Anak melakukan perbuatan melawan hukum dari berbagai jenis tindak pidana, seperti halnya begal, pencurian dengan pemberatan, pencurian dengan kekerasan, pencabulan, penganiayaan, narkotika dan lain sebagainya, dimana pemidanaan tersebut anak di tempatkan di Lembaga Pembinaan Khusus Anak (LPKA). Kondisi seperti ini anak-anak sangat rentan mendapatkan perlakuan diskriminatif. Oleh karenanya Anak harus dilindungi dari salahnya pengimplementasian suatu pengaturan yang diimplementasikan kepada dirinya, sehingga menimbulkan banyak kerugian terhadap anak tersebut, dan perlindungan seperti ini disebut sebagai perlindungan hukum. ${ }^{14}$

Seringkali terdengar bahwa masih adanya keluhan-keluhan dari keluarga dan narapidana anak terhadap dugaan pelanggaran pelaksanaan hak hak anak sebagai anak pidana, dimana hakhak anak yang telah diatur di dalam suatu peraturan perundang-undangan belum sepenuhnya terlaksana pada Lembaga Pembinaan Khusus Anak (LPKA), seperti halnya jumlah penghuni yang tidak sebanding dengan kapasitas ruangan yang ada LPKA itu sendiri, tentang kesejahteraan anak, sandang dan pangan nya belum diperhatikan secara baik dan layak sehingga anak seringkali mengeluh sakit, minimnya fasilitas pendidikan juga berpengaruh pada kegiatan belajar anak, ruangan kelas terbatas sehingga belum bisa menampung secara keseluruhan proses belajar mengajar anak pidana, anak anak pidana yang awalnya putus sekolah dipisah dengan anak pidana yang sebelumnya bersekolah, serta belum mendapatkan hak nya untuk mengikuti

\footnotetext{
${ }^{6}$ Abintoro Prakoso, Hukum Perlindungan anak, Yogyakarta: LaksBang PRESSindo, (2016), hlm 23.

${ }^{7}$ Emeliana Krisnawati, Aspek Hukum Perlindungan Anak, Bandung: Utomo, (2005), hlm3.

${ }^{8}$ Nikmah Rosidah Budaya Hukum Hakim Anak Di Indonesia sebuah pendekatan hukum progresif, Semarang: Pustaka Magister, (2014), hlm 47-48.

${ }^{9}$ Maidin Gultom, Op.Cit., hlm.38.

${ }^{10}$ Abintoro prakoso, Op.Cit., hlm 17.

${ }^{11}$ Mohammad Taufik Makarao, Op.Cit, hlm. 67.

${ }^{12}$ Eddy O.S. Hiariej, Prinsip-prinsip Hukum Pidana, Yogyakarta: Cahaya Atma Pustaka, (2016), hlm 34.

${ }^{13}$ Sumber Data Lembaga Pembinaan Khusus Anak Bandar Lampung, per 30 Maret 2017.

${ }^{14}$ Ibid., hlm. 2.
} 
kegiatan belajar mengajar, fasilitas bermain juga kurang memadai, fasilitas kesehatan juga masih terbatas, kegiatan spritual dan kajian rohani belum secara rutin diadakan, fasilitas anak untuk tumbuh berkembang sesuai dengan bakat dan minatnya, bahkan terpidana anak juga rentan mendapatkan kekerasan dari temannya sesama narapidana.

Namun dalam hal ini penulis memfokuskan penulisan hanya terbatas pada pelaksanaan hakhak anak sebagai pidana begal yang ada di dalam Lembaga Pembinaan Khusus Anak (LPKA). Adakah perlakuan yang berbeda tentang pelaksanaan hak-hak anak terhadap anak pidana begal dengan terpidana anak yang lainnya, termasuk hak-hak untuk mendapatkan pengurangan masa pidana, asimilasi, cuti mengunjungi keluarga, pembebasan bersyarat, cuti menjelang bebas, dan cuti bersyarat, mengingat pelaku begal perbuatannya begitu sadis dan sangat kejam bahkan tak segan-segan membunuh korbannya, sehingga meresahkan masyarakat di bumi Lampung ini. Memperhatikan fenomena di atas penulis tertarik ingin menganalisis tentang Pelaksanaan HakHak Anak Sebagai Anak Pidana Begal. (Studi di Lembaga Pembinaan Khusus Anak (LPKA) Klas II Bandar Lampung), karena walaupun anak pidana begal mereka mempunyai hak-hak yang tidak boleh dilanggar, dan mereka juga masih membutuhkan pembinaan, arahan dan kasih sayang dari keluarganya dan masyarakat.

Adapun masalah yang akan dibahas pada penelitian ini adalah tentang bagaimanakah pengimplementasian hak-hak anak sebagai anak pidana begal di Lembaga Pembinaan Khusus Anak? Dan Mengapa terdapat faktor penghambat dalam pelaksanaan hak-hak anak sebagai anak pidana begal di Lembaga Pembinaan Khusus Anak? Jenis penelitian yang digunakan dalam penelitian ini yakni penelitian hukum yuridis normatif dan yuridis empiris, yuridis normatif adalah pendekatan melalui studi kepustakaan (library research) yang berhubungan dengan permasalahan dalam penelitian.Selanjutnya pendekatan yuridis empiris yang dilakukan dengan cara mengadakan penelitian lapangan dengan melihat kenyataan yang ada. Data yang digunakan adalah data sekunder dan data primer, data primer adalah data yang didapat dengan cara melakukan penelitian langsung terhadap objek penelitian dengan cara wawancara terhadap narasumber. Data sekunder adalah data yang diperoleh dari berbagai sumber hukum yang berhubungan dengan permasalahan yang diteliti. Data sekunder terdiri dari bahan hukum primer, bahan hukum sekunder, dan bahan hukum tersier. Analisis bahan dalam penelitian ini dilakukan secara kualitatif.

\section{B. Pembahasan}

\section{Pelaksanaan Hak Hak Anak Sebagai Anak Pidana Begal di Lembaga Pembinaan Khusus Anak (LPKA)}

Masuknya anak pidana ke dalam Lembaga Pembinaan Khusus Anak merupakan titik awal dimulainya usaha pembinaan anak pidana baik pisik maupun mental, dengan cara memberikan hak-haknya sebagai anak pidana ketika anak pidana menjalani hukuman yaitu berupa pemidanaan di LPKA. Hak-hak anak yang menjalani masa hukuman pidana diatur dalam Pasal 4 Undang-Undang Republik Indonesia Nomor 11 Tahun 2012 tentang Sistem Peradilan Pidana Anak. Pasal 4 ayat (1) mengatur tentang anak yang menjalani masa pidana berhak; a) mendapat pengurangan masa pidana; b) memperoleh asilimilasi: c) memperoleh cuti mengunjungi keluarga; d) memperoleh pembebasan bersyarat; e) memperoleh cuti menjelang bebas; f) memperoleh cuti bersyarat; g) memperoleh hak lain sesuai dengan ketentuan peraturan perundang-undangan.

Pasal 14 Undang-Undang Nomor 12 Tahun 1995 Tentang Pemasyarakatan menyebutkan tentang hak-hak narapidana sebagai berikut:

a. Narapidana berhak :

1) melakukan ibadah sesuai dengan agama atau kepercayaannya;

2) mendapat perawatan, baik perawatan rohani maupun jasmani;

3) mendapatkan pendidikan dan pengajaran;

4) mendapatkan pelayanan kesehatan dan makanan yang layak;

5) menyampaikan keluhan; 
6) mendapatkan bahan bacaan dan mengikuti siaran media massa lainnya yang tidak dilarang;

7) mendapatkan upah atau premi atas pekerjaan yang dilakukan;

8) menerima kunjungan keluarga, penasihat hukum, atau orang tertentu lainnya;

9) mendapatkan pengurangan masa pidana (remisi);

10) mendapatkan kesempatan berasimilasi termasuk cuti mengunjungi keluarga;

11) mendapatkan pembebasan bersyarat;

12) mendapatkan cuti menjelang bebas; dan

13) mendapatkan hak-hak lain sesuai dengan peraturan perundang-undangan yang berlaku.

Pelaksanaan hak-hak anak di LPKA mengacu pada Undang-Undang Nomor 11 Tahun 2012 tentang Sistem Peradilan Pidana Anak, dan berpedoman pada Undang-Undang Nomor 12 Tahun 1995 tentang Pemasyarakatan. Dikarenakan hak-hak anak pidana tentang Pengurangan Masa Pidana, Asimilasi, Cuti Mengunjungi Keluarga (CMB), Pembebasan Bersyarat (PB), Cuti Menjelang Bebas, Cuti Bersyarat, belum ada undang-undang yang mengatur secara khusus. Data yang ada di LPKA Klas II Bandar Lampung selama kurun waktu Tahun 2015 ada 24 anak pidana begal, Tahun 2016 ada 28 anak pidana begal, dan sampai dengan bulan April 2017 sebanyak 39 orang anak pidana begal yang masih menjalani masa pidananya di LPKA. Lembaga Pembinaan Khusus Anak (LPKA) ruang lingkupnya Propinsi Lampung, artinya LPKA menampung anak pidana dari seluruh Provinsi Lampung. Pelaksanaan hak hak anak sebagai anak pidana begal di LPKA sudah terlaksana sesuai peraturan perundang-undangan seperti hal nya hak-hak tentang:

1. Mendapat pengurangan masa pidana (Remisi)

Anak pidana mendapatkan pengurangan masa pidana (Remisi) setelah lebih dahulu menjalani hukuman pidana selama 6 bulan, dalam 1 tahun ada 3 kali remisi yaitu; Remisi Khusus Hari Raya Idul Fitri, Remisi Hari Anak Nasioanal (REHAN), dan Remisi Hari Kemerdekaan RI tanggal 17 Agustus, masing-masing selama 15 hari.

2. Memperoleh kesempatan berasimilasi termasuk cuti mengunjungi keluarga; Terlaksana sesuai dengan prosedur,

3. Mendapatkan pembebasan bersyarat

Anak yang sedang menjalani masa pidananya di LPKA mendapatkan hak untuk mengajukan Pembebasan Bersyarat (PB) jika telah memenuhi syarat telah menjalani masa pidana paling sedikit $1 / 2$ (satu per dua) masa pidana dan berkelakuan baik selama menjalani masa pidana.

4. Mendapatkan cuti menjelang bebas

Cuti Menjelang Bebas belum membudaya di LPKA, mungkin karena anak-anak jadi belum begitu penting, tetapi jika ada permintaan keluarga sesuai dengan Standar Operasioanl Prosedure (SOP) akan dilaksanakan.

5. Mendapatkan cuti bersyarat;

Terlaksana sesuai dengan prosedur dan syarat- syarat yang ditentukan, dipidana dengan pidana penjara selama 1 (satu) tahun 6 (enam) bulan, usia anak kurang dari 18 tahun dipotong 1/2 (satu perdua) masa pidana, berkelakuan baik selama kurun waktu 6 bulan terakhir.

6. Mendapatkan hak-hak lain sesuai dengan peraturan perundang-undangan yang berlaku, yang mengacu pada undang-undang Sistem Peradilan Pidana Anak, dan berpedoman pada undang-undang Pemasyarakatan.

7. Melakukan ibadah sesuai dengan agama atau kepercayaannya. Anak pidana yang berada dalam LPKA mayoritas $99 \%$ beragana Islam, mereka melakukan ibadah dan sholat berjamaah di Masjid, ada 1 orang anak pidana yang beragama hindu, dan 1 orang anak yang beragama nasrani, yang melakukan bimbingan rohaninya adalah pegawai LPKA yg beragama nasrani, karena gereja belum aktif.

8. Mendapat perawatan, baik perawatan rohani maupun jasmani. LPKA beberapa tahun yang lalu telah bekerjasama dan mengadakan Memorandum Of Understanding (MOU) dengan Majelis Taklim Al-Kirom Tegineneng Natar, LPKA juga sudah bekerjasama dan 
mengadakan Memorandum Of Understanding (MOU) dengan Universitas Muhammadiyah Lampung Fakultas Psikologi, untuk menangani anak-anak pidana yang prilakunya tidak baik atau yang mengalami depresi pasca putusan pengadilan. Anak pidana mendapatkan pendidikan dan pengajaran di dalam LPKA, Pihak LPKA mengadakan Memorandum of Undestanding (MOU) dengan Yayasan Pendidikan Dwi Mulya, adapun guru-gurunya setiap hari mengajar anak pidana di LPKA, kurikulum sama seperti sekolah umum, ruang kelas luas ada 4 (empat) ruang kelas tetapi 1 (satu) kosong tidak terpakai. Jumlah murid Sekolah Dasar (SD) 10 orang, Sekolah Menengah Pertama 25 orang, dan Sekolah Menengah Atas 35 orang per kelas. Anak pidana juga mendapat pelatihan kerja yaitu berupa kerajinan tangan (handycraft) pembuatan souvenir dari bahan dasar kayu, dan Perkebunan tanaman hias, dalam hal ini LPKA bekerjasama dengan Politekhnik Negeri Unila (Polinela) Bandar Lampung untuk mengajari anak-anak pidana berkebun tanaman hias, juga ada alat musik lengkap bagi anak pidana yang punya bakat dan minat bermain musik.

9. Mendapatkan pelayanan kesehatan dan makanan yang layak; Sudah ada klinik kesehatan, tetapi untuk saat ini belum ada dokter jaga, Jadi LPKA bekerjasama mengadakan Memorandum Of Understanding (MOU) dengan Pusat Kesehatan Masyarakat (Puskesmas) Tegineneng Pesawaran, setiap minggu $2-3$ kali anak pidana cek kesehatan, Anak pidana mendapatkan makanan yang layak 3 kali sehari, air minum, lauk dan sayur cukup, sehingga gizinya tercukupi.

10. Menyampaikan keluhan; Anak pidana bebas berkomunikasi dan menyampaikan keluhan tentang permasalahan yang dihadapinya kepada petugas.

11. Mendapatkan bahan bacaan dan mengikuti siaran media massa lainnya yang tidak dilarang; Sudah mendapatkan hak tersebut tetapi bahan-bahan bacaan terbatas, LPKA mendapatkan sumbangan buku-buku dari instansi terkait, disetiap wisma disiapkan 1 unit televisi sehingga anak pidana dapat menonton siaran televisi yang tidak dilarang.

12. Menerima kunjungan keluarga, penasihat hukum, atau orang tertentu lainnya. Anak pidana begal bebas menerima kunjungan dari keluarga, Penasihat Hukum atau orang tertentu lainnya sepanjang dapat mengikuti tata tertib yang ada di LPKA.

13. Mendapatkan upah atau premi atas pekerjaan yang dilakukan; Hal ini tidak berlaku bagi anak pidana yang berada di LPKA, tetapi berlaku untuk terpidana dewasa di Lembaga Pemasyarakatan.

Terkait dengan pelaksanaan hak-hak anak sebagai anak pidana begal di LPKA Kelas II Bandar Lampung, penulis juga mewawancarai 3 (tiga) orang anak pidana begal yang berinisial SDC, HS, dan B, pada intinya anak pidana begal tersebut menyebutkan bahwa hak-hak mereka sebagai anak pidana begal di dalam LPKA sudah terlaksana, meski ada anak begal yang tidak bisa melanjutkan sekolahnya. Pelaksanaan hak-hak anak pidana dan anak pidana begal di LPKA Klas II Bandar Lampung, dapat digambarkan seperti dalam tabel dibawah ini.

Tabel 1. Pelaksanaan Hak-hak anak pidana dan Anak Pidana Begal

\begin{tabular}{|c|c|c|c|c|}
\hline No & Hak-hak Anak & Terlaksana & $\begin{array}{l}\text { Tidak } \\
\text { Terlaksana }\end{array}$ & Keterangan \\
\hline a. & $\begin{array}{l}\text { Melakukan } \\
\text { Ibadah sesuai } \\
\text { dengan agama } \\
\text { Atau kepercayaannya }\end{array}$ & $\sqrt{ }$ & & $\begin{array}{l}\text { Mayoritas Anak pidana } 99 \% \\
\text { beragama Islam, mereka melakukan } \\
\text { ibadah dan sholat berjamaah di } \\
\text { Masjid }\end{array}$ \\
\hline
\end{tabular}




\begin{tabular}{|c|c|c|c|c|}
\hline b. & \begin{tabular}{lr}
\multicolumn{2}{l}{ Mendapatperawatan, } \\
baik & perawatan \\
rohani & maupun \\
jasmani &
\end{tabular} & $\sqrt{ }$ & & $\begin{array}{l}\text { LPKA bekerjasama dan mengadakan } \\
\text { Memorandum of Understanding } \\
\text { (MOU) dengan Majelis Taklim Al- } \\
\text { Kirom Tegineneng Natar. Perawatan } \\
\text { Jasmani, di LPKA ada lapangan } \\
\text { olahraga sehingga anak pidana } \\
\text { bebas melakukan kegiatan olahraga. } \\
\text { Bekerjasama dan mengadakan } \\
\text { Memorandum of Understanding } \\
\text { (MOU) dengan Fakultas Psikologi } \\
\text { Universitas Muhammadiyah } \\
\text { Lampung }\end{array}$ \\
\hline c. & $\begin{array}{l}\text { Mendapatkan } \\
\text { pendidikan dan } \\
\text { pengajaran }\end{array}$ & $\sqrt{ }$ & & $\begin{array}{l}\text { LPKA bekerjasama dan mengadakan } \\
\text { Memorandum of Understanding } \\
\text { (MOU) dengan Yayasan Pendidikan } \\
\text { Dwi Mulya untuk proses belajar } \\
\text { mengajar anak pidana di dalam } \\
\text { LPKA. }\end{array}$ \\
\hline $\mathrm{d}$. & $\begin{array}{l}\text { Mendapatkan } \\
\text { pelayanan kesehatan } \\
\text { dan makanan yang } \\
\text { layak }\end{array}$ & $\sqrt{ }$ & & $\begin{array}{l}\text { Anak pidana mendapatkan makanan } \\
\text { yang layak } 3 \text { kali sehari, menu } 4 \\
\text { sehat } 5 \text { sempurna. LPKA } \\
\text { bekerjasama dan mengadakan } \\
\text { Memorandum of Understanding } \\
\text { (MOU) dengan Puskesmas } \\
\text { Tegineneng. }\end{array}$ \\
\hline e. & $\begin{array}{l}\text { Menyampaikan } \\
\text { keluhan }\end{array}$ & $\sqrt{ }$ & & $\begin{array}{l}\text { Anak pidana bebas berkomunikasi } \\
\text { dan berinteraksi dengan petugas di } \\
\text { LPKA untuk menyampaikan } \\
\text { keluhan. }\end{array}$ \\
\hline f. & $\begin{array}{l}\text { Mendapatkan bahan } \\
\text { bacaan dan mengikuti } \\
\text { siaran media massa } \\
\text { lainnya yang tidak } \\
\text { dilarang }\end{array}$ & $\sqrt{ }$ & & $\begin{array}{l}\text { LPKA mendapatkan sumbangan } \\
\text { buku-buku dan Televisi (TV) } \\
\text { disiapkan di setiap wisma. }\end{array}$ \\
\hline g. & $\begin{array}{l}\text { Mendapatkan upah } \\
\text { atau premi atas } \\
\text { pekerjaan yang } \\
\text { dilakukan }\end{array}$ & & $\sqrt{ }$ & $\begin{array}{l}\text { Tidak berlaku untuk anak-anak di } \\
\text { LPKA (ini khusus di LP orang } \\
\text { dewasa) }\end{array}$ \\
\hline h. & $\begin{array}{l}\text { Menerima kunjungan } \\
\text { keluarga, penasihat } \\
\text { hukum, atau orang } \\
\text { tertentu lainnya }\end{array}$ & $\sqrt{ }$ & & $\begin{array}{l}\text { Keluarga, penasihat hukum, dan } \\
\text { orang tertentu lainnya bebas } \\
\text { mengunjungi anak pidana dari pagi } \\
\text { s/d sore (jam kerja) }\end{array}$ \\
\hline i. & $\begin{array}{l}\text { Mendapatkan } \\
\text { pengurangan } \\
\text { Masa pidana (remisi) }\end{array}$ & $\sqrt{ }$ & & $\begin{array}{l}\text { Pengurangan masa pidana (remisi) } \\
\text { didapatkan anak pidana begal } \\
\text { sebanyak } 3 \text { kali dalam satu tahun } \\
\text { setelah menjalani terlebih dahulu } \\
\text { hukuman selama enam bulan, yaitu } \\
\text { setiap hari Kemerdekaan tanggal } 17 \\
\text { Agustus, Hari Anak Nasional dan } \\
\text { setiap Hari Raya. }\end{array}$ \\
\hline j. & Mendapatkan & $\sqrt{ }$ & & Terlaksana sesuai dengan prosedur, \\
\hline
\end{tabular}




\begin{tabular}{|c|c|c|c|c|}
\hline & $\begin{array}{l}\text { kesempatan } \\
\text { berasimilasi termasuk } \\
\text { cuti mengunjungi } \\
\text { keluarga }\end{array}$ & & & $\begin{array}{l}\text { melihat dari kepribadian } \\
\text { dan perilaku anak pidana begal. }\end{array}$ \\
\hline k. & $\begin{array}{l}\text { Mendapatkan } \\
\text { pembebasan } \\
\text { bersyarat }\end{array}$ & $\sqrt{ }$ & & $\begin{array}{l}\text { Terlaksana sesuai dengan prosedur, } \\
\text { melihat dari kepribadian } \\
\text { dan perilaku anak pidana begal. }\end{array}$ \\
\hline 1. & $\begin{array}{l}\text { Mendapatkan } \\
\text { Cuti menjelang bebas }\end{array}$ & & $\sqrt{ }$ & $\begin{array}{l}\text { Belum membudaya karena mungkin } \\
\text { dirasa belum begitu penting bagi } \\
\text { anak-anak, tapi } \\
\text { jika ada permintaan keluarga sesuai } \\
\text { dengan Standar Operasional } \\
\text { Prosedure (SOP) akan } \\
\text { dilaksanakan. }\end{array}$ \\
\hline $\mathrm{m}$. & $\begin{array}{l}\text { Mendapatkan cuti } \\
\text { bersyarat }\end{array}$ & $\sqrt{ }$ & & $\begin{array}{l}\text { Terlaksana sesuai dengan prosedur, } \\
\text { melihat dari kepribadian } \\
\text { dan perilaku anak pidana begal. }\end{array}$ \\
\hline n. & $\begin{array}{l}\text { Mendapatkan hak- } \\
\text { hak lain sesuai } \\
\text { dengan peraturan } \\
\text { perundang- } \\
\text { undangan yang } \\
\text { berlaku yaitu; } \\
\text { Undang Undang } \\
\text { Nomor } 11 \text { Tahun } \\
2012 \text { tentang Sistem } \\
\text { Peradilan Pidana } \\
\text { Anak dan Undang- } \\
\text { Undang Nomor } 12 \\
\text { Tahun } 1995 \\
\text { tentang } \\
\text { Pemasyarakatan. }\end{array}$ & $\sqrt{ }$ & & \\
\hline
\end{tabular}

Sebagaimana uraian penjelasan yang tergambar dari tabel diatas, pelaksanaan hak- hak anak sebagai anak pidana begal pada Lembaga Pembinaan Khusus Anak (LPKA) Kelas II Bandar Lampung sebagian besar sudah dilaksanakan. Dalam menjalankan hukum terdapat 3 syarat yang selalu harus diperhatikan, yaitu: kepastian hukum, kebermanfaatan, serta keadilan. Hukum itu bersifat umum, mengikat setiap orang. Seharusnya dalam mengimplementasikan suatu hukum harus memenuhi ke-3 syarat yang telah disebutkan sebelumnya. Pelaksanaan penegakan hukum pidana yang rasional terdiri dari tiga tahap yaitu tahap formulasi, tahap aplikasi, dan tahap eksekusi. Pelaksanaan hak-hak anak sebagai anak pidana begal termasuk dalam tahap eksekusi ialah suatu tahap di mana pelaksanaan hukum pidana dilaksanakan secara menyeluruh oleh petugas pelaksana pidana, petugas tersebut harus melaksanakan suatu peraturan yang telah dibuat oleh para pembentuk undang-undang melalui penetapan pengadilan. Para petugas pelaksana ketika melaksanakan tugasnya harus berpedoman kepada suatu peraturan pidana seperti yang telah dibentuk oleh legislator. Dari 13 (tiga belas) hak-hak anak sebagai anak pidana begal di Lembaga Pembinaan Khusus Anak (LPKA) Klas II Bandar Lampung, ada 11 (sebelas) hak anak pidana begal yang sudah terlaksana.

Lembaga Pemasyarakatan dalam hal ini Lembaga Pembinaan Khusus Anak bukan hanya sekedar tempat membina, mendidik manusia (anak pidana), LPKA juga diharapkan dapat mewujudkan tujuan akhir dari sistem peradilan pidana yaitu mencegah timbulnya kembali kejahatan yang dilakukan. Pelaksanaan pembinaan anak pidana di LPKA telah memiliki tempat yang layak dan strategis, memiliki infrastruktur bangunan yang berdiri megah di atas tanah dan halaman yang luas, asri dan nyaman, seyogyanya tetap dipertahankan pengelolaannya dengan 
baik karena di sanalah proses memanusiakan manusia dengan menjadikan prilaku anak pidana yang tadinya tidak sesuai dengan norma-norma yang ada akan dikembalikan menjadi baik dan dapat diterima kembali di dalam lingkungan masyarakat. Tujuan dari hukum pidana anak yaitu bertujuan mengembalikan kejiwaan anak tersebut yang disebabkan oleh tindakan pidana yang dilakukannya. Maksudnya adalah tujuan dari suatu pidana tidak hanya untuk menghukum pelaku pidana, tetapi juga membina serta menyadarkan anak yang telah melakukan perbuatan menyimpang, sehingga diharapkan anak yang telah menjalani hukuman akan mempunyai kehidupan yang lebih baik, karena sejatinya anak adalah generasi penerus bangsa, yang akan memegang tanggung jawab negara.

\section{Faktor Penghambat Dalam Pelaksanaan Hak-Hak Anak Sebagai Anak Pidana Begal Di Lembaga Pembinaan Khusus Anak (LPKA) Klas II Bandar Lampung}

Inti dari permasalahan hukum terdapat banyak faktor penyebab yang mempengaruhinya, yakni; Faktor perundang-undangan (substansi hukum), penegak hukum, sarana atau fasilitas pendukung penegakan hukum, masyarakat dan kebudayaan. Namun dalam hal ini menururt analisa penulis fakta yang terjadi di dalam Lembaga Pembinaan Khusus Anak (LPKA) Klas II Bandar Lampung, faktor yang mempengaruhi dan yang menjadi penghambat paling dominan adalah pertama Faktor Masyarakat mempunyai pengaruh yang sangat kuat dalam penegakan hukum, hal ini dikarenakan masyarakat merupakan objek hukum yang digunakan untuk mencapai tujuan hukum yaitu kedamaian dalam suatu masyarakat, hukum dibuat untuk menciptakan ketertiban dalam masyarakat, semakin luas pengetahuan masyarakat maka semakin tinggi kesadaran hukumnya. Dalam hal pelaksanaan hak- hak anak sebagai anak pidana begal pengaruh masyarakat sangatlah besar, sebab setelah anak pidana begal di tempatkan dalam LPKA, keluarga seolah-olah mempasrahkan sepenuhnya pembinaan anak pidana kepada petugas LPKA, serta tidak memperdulikan kebutuhan-kebutuhan anak pidana, seperti halnya keluarga tidak rutin menjenguk atau mengunjungi anak, tidak mengurus kelengkapan adiminsitrasi sehingga anak pidana tidak bisa melanjutkan sekolahnya, tidak mengurus kartu Badan Penyelenggara Jaminan Sosial (BPJS), jika anak pidana begal sakit, serta tidak memberikan perhatian dan kasih sayang selama anak pidana menjalani hukuman, bahkan ada istilah anak hilang di dalam LPKA, yaitu anak yang tidak pernah dikunjungi oleh keluarganya. Sikap keluarga dan masyarakat yang tidak mendukung dan cenderung menganggap tugas pelaksanaan hak-hak anak pidana begal semata- mata adalah menjadi tugas dan tanggung jawab petugas aparat penegak hukum. Faktor penghambat kedua, ialah aparat penegak hukum yang harus melaksanakan tugasnya dengan benar sesuai dengan yang telah diatur dalam peraturan perundang- undangan. Dalam melaksanakan tugas tersebut aparat penegak hukum seyogyanya mendahulukan keadilan dan profesionalisme, sehingga akan menjadi contoh semua pihak termasuk anggota masyarakat. Pelaksanaan hak-hak anak sebagai anak pidana begal di LPKA terjadi hambatan karena kurangnya koordinasi antara instansi Kejaksaan Negeri dan Pengadilan Negeri dalam hal pengiriman surat eksekusi dan surat ekstra vonis anak pidana. Surat Ekskusi P. 48 /BA.17 kendati putusan sudah inkrach tetapi ekstra vonis dan eksekusinya seringkali terlambat pengirimannya LPKA, hal tersebut tentunya berpengaruh dan menghambat arah pembinaan anak pidana kedepannya. Hal demikian juga dapat mencerminkan kurangnya pemahaman petugas administrasi Pengadilan Negeri dan petugas administrasi Kejaksaan Negeri tentang pelaksanaan hak-hak anak pidana pada umumnya. Penegakan hukum akan terwujud apabila masyarakat sadar hukum, kesadaran hukum merupakan suatu proses psikis dan nilainilai yang berada dalam diri manusia, kurang berpartisipasinya masyarakat akan menjadi kendala dan mempengaruhi pelaksanaan penegakan hukum. Hal tersebut berhubungan dengan berjalannya fungsi hukum pada masyarakat atau efektifitas dari implementasi hukum, mengingat persoalan Anak Berkonflik dengan Hukum atau anak pidana tidak saja sebatas permasalahan hukum, tetapi juga wajib melihat permasalahan sosial.

\section{Kesimpulan}

Pelaksanaan hak-hak anak sebagai anak pidana begal di LPKA Klas II Bandar Lampung, mengacu pada Undang-Undang Nomor 11 Tahun 2012 tentang Sistem Peradilan Pidana Anak, 
dan berpedoman pada Undang Undang Nomor 12 Tahun 1995 tentang Pemasyarakatan. Dari 13 (tiga belas) hak-hak anak sebagai anak pidana begal, ada 11 (sebelas) hak anak pidana begal yang sudah terlaksana meskipun belum sempurna. Faktor penghambat dari masyarakat dan aparat penegak hukum, yakni tidak ada kepedulian keluarga terhadap anak pidana begal, adapun pembinaan anak pidana begal dipasrahkan sepenuhnya kepada petugas di LPKA, serta kurangnya koordinasi antara Instansi terkait yaitu Kejaksaan Negeri dan Pengadilan Negeri dengan Lembaga Pembinaan Khusus Anak (LPKA).

\section{Saran}

Pemerintah harus mengadakan sosialisasi dan memberikan penyuluhan hukum kepada masyarakat terutama di daerah asal mayoritas anak pidana mengenai pola asuh anak, ketahanan keluarga, serta pengetahuan hukum, keluarga dan masyarakat seharusnya lebih peduli dan memperhatikan hak- hak anak pidana begal, tidak memasrahkan sepenuhnya pembinaan anak kepada petugas Lembaga Pembinaan Khusus Anak (LPKA).

Perlu adanya koordinasi yang baik antara Instansi terkait yakni Kejaksaan Negeri, Pengadilan Negeri, dengan Lembaga Pembinaan Khusus Anak (LPKA), serta peningkatan pendidikan bagi petugas administrasi di Kejaksaan Negeri dan Pengadilan Negeri, sehingga kedepannya tidak ada lagi keterlambatan pengiriman dokumen ke LPKA.

\section{A. Buku}

\section{DAFTAR PUSTAKA}

Emeliana Krisnawati. (2005). Aspek Hukum Perlindungan Anak. Bandung: Utomo.

Gultom, Maidin. (2013). Perlindungan Hukum Terhadap Anak Dalam Sistem Peradilan Pidana Anakdi Indonesia. Bandung: Refika Aditama.

Hiariej, Eddy O.S. (2016). Prinsip-prinsip Hukum Pidana. Yogyakarta: Cahaya Atma Pustaka

Mohammad Taufik Makarao, Letkol Sus, Weny Bukamo, Syaiful Azri. (2013). Hukum Perlindungan Anak dan Penghapusan Kekerasan Dalam Rumah Tangga. Jakarta: Rineka Cipta.

Prakoso, Abintoro. (2016). Hukum Perlindungan Anak. Yogyakarta: LaksBang PRESSindo

Qamar, Nurul. (2016). Hak Asasi Manusia dalam Negara Hukum Demokrasi (Human Rights in Democratiche Rechtsstaat). Jakarta: Sinar Grafika.

Rosidah, Nikmah. (2014), Budaya Hukum Hakim Anak Di Indonesia Sebuah Pendekatan Hukum Progresif. Semarang: Pustaka Magister.

Zaidan, M. Ali. (2016). Kebijakan Kriminal. Jakarta: Sinar Grafika. 